\title{
Flood policy in Spain: a review for the period 1983-2013
}

Flood policy in Spain

\author{
Jorge Olcina \\ Institute of Geography, University of Alicante, Alicante, Spain \\ David Sauri \\ Department of Geography, Autonomous University of Barcelona, \\ Bareclona, Spain \\ Maria Hernández \\ Institute of Geography, University of Alicante, Alicante, Spain, and \\ Anna Ribas \\ Department of Geography, Universitat of Girona, Girona, Spain
}

\begin{abstract}
Purpose - The purpose of this paper is to assess the main changes regarding flood policy in Spain during the period 1983-2013, that is right after the large and very damaging episodes of 1982-1983 in Valencia, Catalonia and the Basque Country.

Design/methodology/approach - This is above all a review paper that looks retrospectively at flood policy in Spain during the past three decades. In order to collect and organize the information the authors follow the methodology of the IPCC regarding vulnerability studies. That is, the authors provide evidence for an overall assessment of the evolution of exposure, sensibility and adaptive capacity to floods in Spain for the period of reference. The authors approach these issues through the own experience and expertise on this subject as noted in the reference list.

Findings - While exposure to floods has generally increased (especially after the massive growth of urbanization in flood prone land of the 1990s and early 2000s) overall flood policy has contributed to make Spain less sensible and more adapted to floods. Still some issues remain unsolved especially the control of urban growth and the adaptation of the built environment to floods. For these reasons absolute economic losses from floods may continue to be important in the future (perhaps more so with climate change) even though, overall, Spanish society may have become less vulnerable and therefore more resilient than in the past.

Originality/value - The paper provides a retrospective study and assessment of policies taken and their changes regarding floods at a national level over a long period of time (30 years) which is a theme still relatively little explored in the scientific literature on this hazard.
\end{abstract}

Keywords Disasters, Floods, Natural hazard, Spain, Adaptive capacity, Emergency response, Manmade disaster, Exposure

Paper type General review

\section{Introduction: the historical context of floods in Spain}

Floods remain the single natural hazards causing the largest economic and social impacts worldwide (Guha-Sapir and Hoyois, 2015). In Spain and according to the "Consorcio de Compensación de Seguros" (a public institution providing insurance against certain natural and social hazards) average flood damages amount to some 800 million euro annually. Taking into account only insured goods, between 1971 and 2012, 42.9 percent of the claims arriving at the Consorcio were flood related. In turn

This work was supported by the Spanish CICYT under Grants Nos CS02012-36997-C02-01, CS02012-36997-C02-02 and CSO2013-41262-P. The authors would like to thank Alfonso Najera for providing data on the economic valuation of flood episodes.

Received 14 May 2015

Revised 21 July 2015 Accepted 8 September 2015 
$\mathrm{DPM}$

25,1

floods represented more than 60 percent of the total compensatory payments in this period (5.3 billion €) (CCS, 2014).

Flood hazards affect virtually all Spain although the most exposed areas can be found along the Mediterranean and Cantabric coasts as well as the Canary Islands. Natural causes of flooding combine meteorological and hydrological drivers while human occupation and transformation of flood prone land is increasingly seen as a dominant exposure and vulnerability factor. Regarding the natural side of the flood equation, precipitation intensity, especially in the Mediterranean basins, may reach extraordinary values. For example, the town of Javea (in the central Mediterranean coast) holds the European record of maximum precipitation in 24 hours with $871 \mathrm{~mm}$ (October 2, 1957) (Olcina, 2009). Values in the Cantabric coast (Larrasquitu, near Bilbao, $500 \mathrm{~mm}$. in August $26,1983)$ are somewhat smaller. In the coastal basins of the Mediterranean and in the mountain ranges of the Pyrenees, precipitation intensities combined with topography, soils, vegetation and land uses produce a scenario of usually violent flash flooding that affects dramatically population and economic activities.

The modification of local and regional hydrological cycles leading toward larger and faster runoffs together with the direct occupation of flood prone land due to factors such as population growth, urban and industrial expansion and the construction of infrastructures has resulted in an overall increase to flood exposure. Some of the more devastating flood episodes of the twentieth century are associated with periods qof distress and hardship (i.e. Catalonia 1940, Murcia 1946 and 1947, Valencia 1957) or periods of rapid socioenvironmental change linked to massive rural urban migration (Catalonia 1962 and 1971; Murcia and Eastern Andalusia, 1973) in which floods caused hundreds of victims among the newly arrived rural immigrants living in flood plains turned into shanty towns.

From the 1980s onwards we assist to the dual process of drastic decreases in human mortality (due to the reduction of precarious dwellings in floodplains and the construction of flood control works) and a parallel and unprecedented increase in the exposure to flooding away from large and medium fluvial courses and into other areas such as coastal and mountain streams and urban environments. The decade began with possibly the last great flood episodes of recent memory: the floods of October 1982 in Valencia; the floods of November 1982 in Andorra and the Catalan Pyrenees and the floods of August 1983 in the Basque Country, the latter possibly the costliest (in economic terms) flood episode in Spanish history. The following years and decades witnessed also important and costly episodes but none of them of the magnitude and impacts of those of the early 1980s.

One possible explanation of this lack of large episodes (at least in terms of human victims) during the past 30 years is the increase in adaptive capacity to floods and the subsequent reduction in vulnerability. With this aim in mind, in this paper it will be developed a retrospective analysis of flood adaptation policy in Spain since the great episodes of the early 1980s. The main hypothesis will be that adaptation measures to flooding have reduced but not eliminated human vulnerability to these phenomena which reappear constantly in different ways. The persistence of a residual vulnerability of an extremely large damage potential is exacerbated by the fact that some of the adaptation measures and very especially land use or urban planning have proven exceedingly difficult to implement. Hence the difference made explicit between exposition and vulnerability which will be stressed throughout this paper.

The paper is organized as follows. After this introduction it is described briefly the most severe flood episodes that have occurred in the country since the mid-1980s. 
Second, it is reviewed the main changes regarding exposure to flooding in the country which to a large extent arise from intense processes of urban and tourist growth. Third, the paper is focussed on adaptation to floods by examining policies and actions taken in the pre, during and post phases of flood occurrence since the mid-1980s. Finally in the conclusions it is attempted to provide an overall assessment of the evolution of exposure, adaptive capacity and vulnerability to floods in Spain during the three decades and also of the Spanish situation with regard to the European Flood Directive of 2007.

\section{Paradigm shifts and pending issues in flood policy}

Flood policy worldwide in recent years continues to mirror water resources policy in that it evolves from single actions such as hard engineering to tame excess water flows to a fuller embracement of the "range of choice approach" developed by Gilbert White 70 years ago (White, 1945). That is, comprehensive flood policy is based on flood control works but also on other actions such as the development of warning systems and emergency planning; the adaptation of the built environment to flood levels, land use planning or flood insurance. The European Flood Directive of 2007, is keen to point out the need of non-structural approaches to the flood problem, and some countries go even further and speak of the need of "Room for Rivers" to stress the shortcoming of

Ollero et al., 2015; Biron et al., 2015). In parallel, a growing number of voices from the environmental field begin to stress the critical importance of flooding for certain socioecological processes.

While these new approaches echoing the turn of flood policies toward more integrated views are gaining momentum, exposure to flooding continues to increase. The pace of urbanization is changing many fluvial environments in the general direction of making flood more likely. Since an increasing amount of material wealth accumulates in dangerous areas, absolute losses may jump extraordinarily even under relatively modest flood events. Growing exposure translates into mounting absolute losses although not necessarily into growing vulnerability because of the effect of the parallel increase in adaptive capacity (White et al., 2001). Hence it is possible to speak plausibly of an increasing societal resilience to a hazard (even under mounting absolute losses) which mostly arises out of the development of adaptive capacities that take into account all stages in the process of disaster occurrence.

\section{The flood episodes of the early 1980s}

In 1982, Spain organized the FIFA World Football Championship, possibly the largest international public event occurring in the country since the Civil War. Spain was still under political turmoil after the military Coup d'Etat of 1981 and the collapse of the center-right political party Unión de Centro Democrático. Just before the National election of October 28, 1982, a flood episode of disastrous consequences took place in the Júcar river basin (Valencia, eastern Spain). Heavy rainfall and rapid increase in flood flows by the Júcar and its tributaries was not, however, the main cause of the catastrophe than ensued in the lower basin. Rather, the most destructive flood wave came after the collapse of the Tous dam and swept the agricultural and urban areas in the floodplains downstream. Some of the effects of this episode were also exacerbated by the obstacles to water flows posed by a major highway running parallel to the coastline. All in all, this episode caused some 30 deaths; 300,000 affected, and more than 2.500 million $€$ in economic losses. The Tous disaster showed the limits of a flood policy strictly based on hydraulic solutions (Mateu, 2000). 
DPM

25,1

Just two weeks after the Valencia episode, in early November 1982, heavy rains in the Catalan Pyrenees, produced another large flood episode. In this case the number of victims (around 20) was significantly smaller than in other episodes of the past in Catalonia such as those of 1940 and 1962 due to the low density of human settlements. However, in relative terms, economic damages in agriculture, livestock and precarious rural communication networks were very significant. This episode made clear the socioenvironmental state of an area suffering from depopulation, crisis of traditional economic activities and a general and secular lack of public investment in basic services.

Third, in late August 1983, another large flood episode in the Basque Country caused the death of 34 people dead and more than three billion pesetas in economic losses. Floods hit especially the industrial towns of Bilbao, Eibar and Llodio then in the middle of a dramatic process of restructuring in the steel, metal and shipbuilding sectors. In economic terms this is still the largest flood disaster experienced in Spain (Barredo et al., 2012).

These three episodes, occurring in less than a year, also happened during a very special period of Spanish recent history coinciding with the ascension to power of the Socialist Party and the beginning of an era in which Spain, which would join the European Union in 1986, spent considerable resources in modernizing the country. Modernization also involved taking first steps in environmental policy including a more comprehensive management of environmental hazards. Public funding not only increased considerably but also expanded from flood control works and post-disaster relief to other actions, especially in flood warning and emergency management. The largest share of the investment pie still went to hydraulic works. Nevertheless, the Water Law of 1985 foresaw the possibility of land use controls in flood prone areas while new hazard monitoring technologies able to register and transmit rainfall and river flow data in real time were introduced in the most problematic basins thus enhancing the predictive capacity of flood warnings. At the same time the creation of a Civil Defense Service (1982) and the elaboration of the first flood emergency plans provided a much needed impetus to the central phases of flood occurrence. This succinct account of policy relevant actions has to be compared with the drivers continuously increasing exposure to floods as we will document in the following section.

\section{Changing exposures and vulnerabilities}

It can be argued that exposure to floods in Spain is increasing substantially since the 1980s. Data in this regard at the country level do not exist but in certain areas such as Catalonia it is estimated that about 15 percent of urban land is located in flood prone areas (Vilaplana, 2008; Sauri, 2011).

Population growth and especially urbanization of areas exposed to floods appear to be major causal factors in explaining growing exposure. Between 1981 and 2011, the population of Spain rose from 37.5 to 46.5 million people. Most of this growth occurred between 2001 and 2011 coinciding with the economic bonanza of the first half of the 2000 s and the massive arrival of immigrants. Within Spain, population growth chiefly concentrated in Madrid, and, very especially, along the Mediterranean coastal areas, including the Balearic Islands, with more than three million people more between 2001 and 2011 (see Figure 1). Foreign population in 2012 reached 5.7 million people (12.2 percent of the total), and, again, it concentrated largely in Madrid and along the Mediterranean coast (see Figure 2).

Population growth is intimately linked with the urbanization process and very especially with the so-called "urbanization tsunami" experienced by the Mediterranean areas between approximately 1995 and 2007. The rapid transformation of former 
Flood policy in Spain

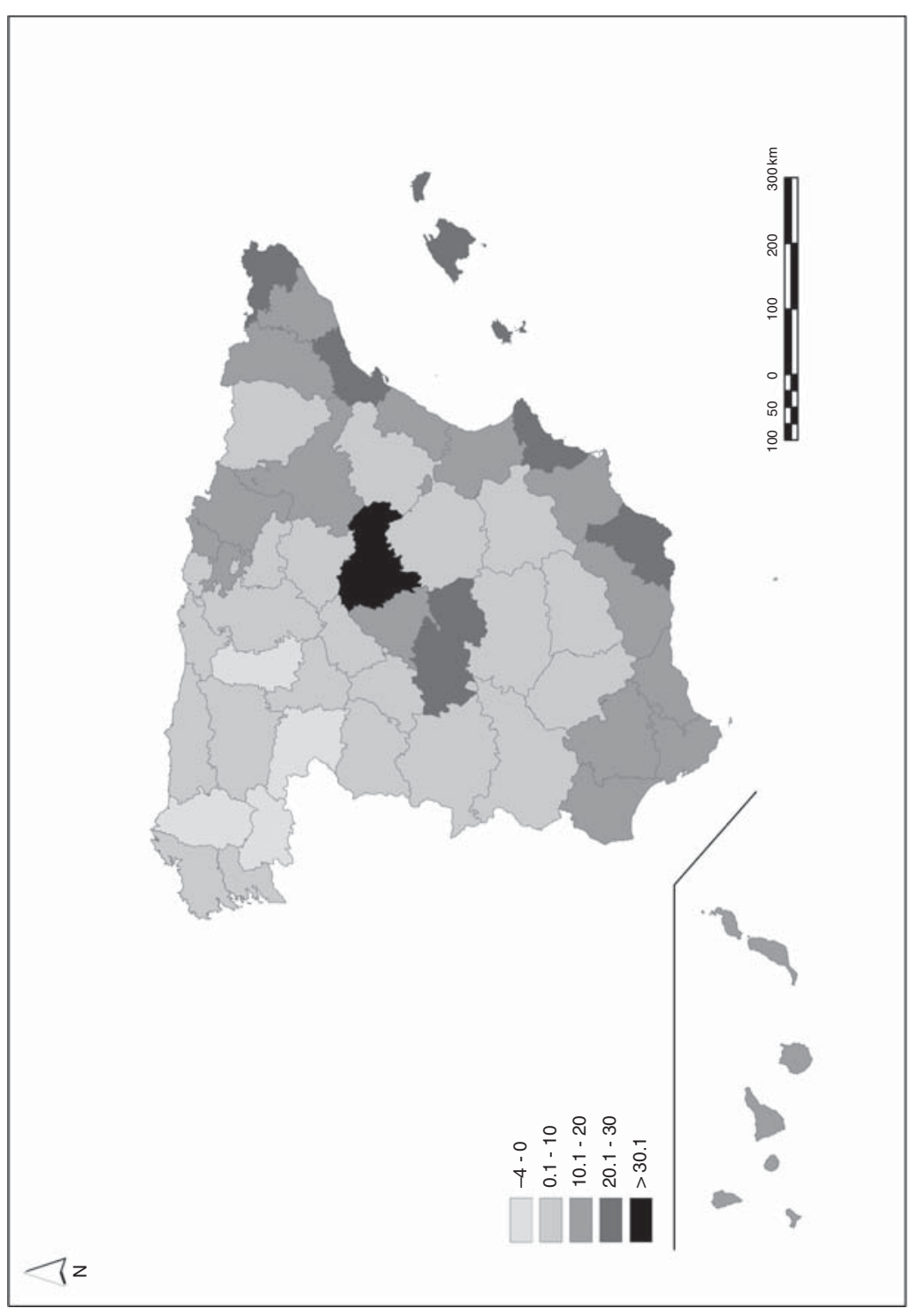

5

Figure 1. 
DPM

25,1

6

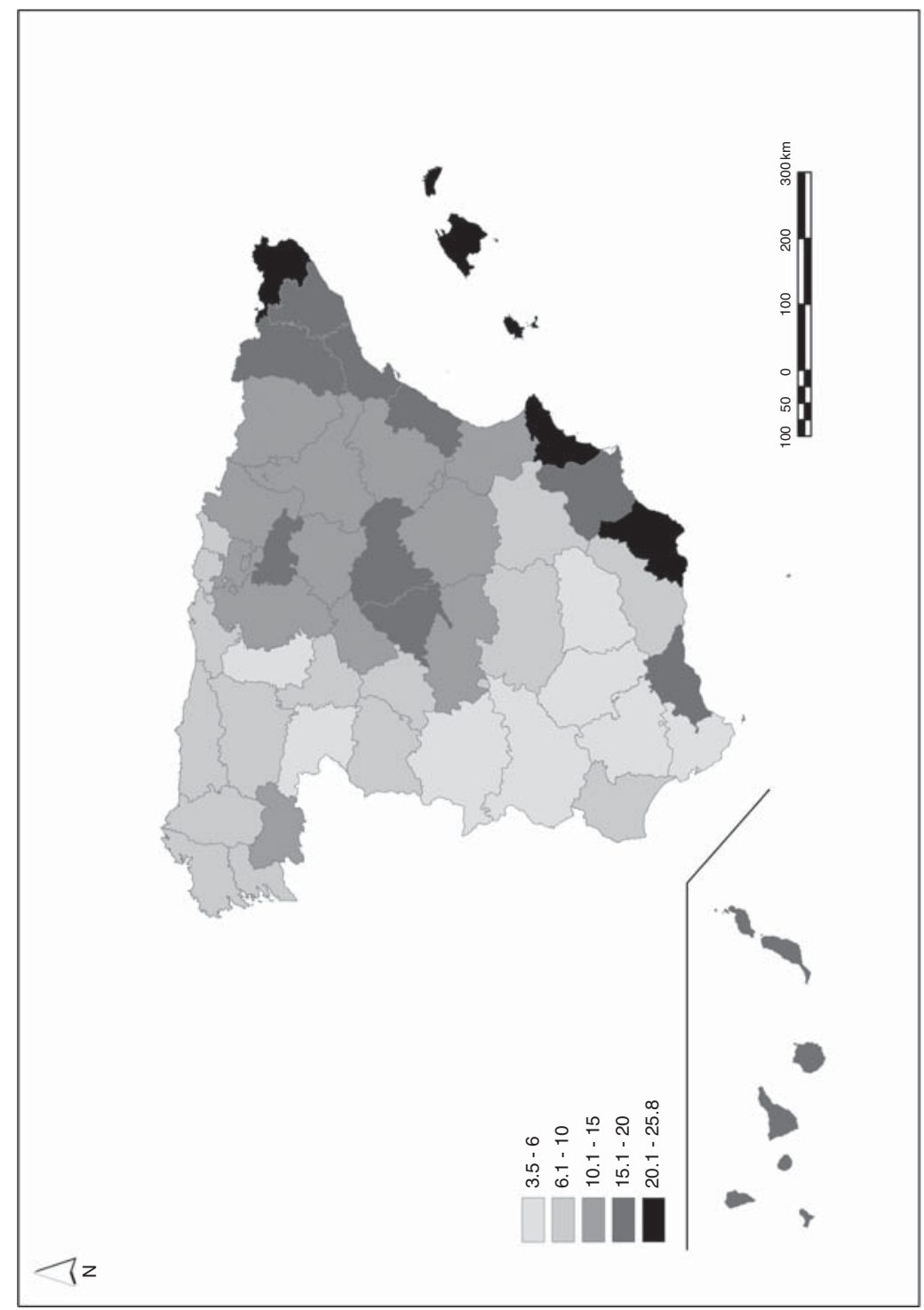

Figure 2.

$\mathrm{XXXX}_{\wedge}$ 
agricultural land into urban land has increased exposure to floods in a process that some of us have called the "littoralization of risk" (Olcina, 2009). In Catalonia, for instance, between 2000 and 2009 more than 210,000 new housing units were built in municipalities classified as of "high flood risk" (Departament de Territori i Sostenibilitat, Generalitat de Catalunya, 2014; Departament d'Interior, Direcció General de Protecció Civil, Generalitat de Catalunya, 2014). In Valencia, flood prone areas totaled some $1,440 \mathrm{~km}^{2}$ in 2013 with almost one million people potentially affected (Generalitat Valenciana, 2013) (see Figure 3).

Urbanization not only contributes to increase peak flows and flood concentration times but exacerbates a rapidly expanding additional problem which is diffuse inundation, probably now the main source of flooding in many coastal tourist zones. Along the Mediterranean, furthermore, the characteristics of the fluvial environment, largely structured in coastal ephemeral streams, distorts an adequate perception of the flood hazard so that urbanization proceeds many times unmindful of the dangerous, nature of flooding in semi-arid areas. Under this relationship between urbanization and ephemeral streams, increase in exposure may take many forms. First, by urbanizing land close to ephemeral streams; second by incorporating fluvial collectors into the city street grid; third by developing land close to the river mouth and near the sea, and, finally even by building directly on river beds. Of particular interests are the periurban spaces recently urbanized in which the uncertainty regarding the manifestations of flooding after the transformation of local water cycles, and the uncertainty mainly regarding experiences with hazards of newly arrived populations have become major sources of concern (Perles, 2010).

While exposure has increased, vulnerability to flooding appears show a decreasing trend at least in what concerns human impacts. Since the early 1980s, the death toll associated with flooding has tended to decrease and single events with more than five people dead have become rare. One of the few and dramatic exceptions to this general trend was the flash flood that ravaged the campsite of Las Nieves, near Biescas (Central Pyrenees) in August 1996. In this episode, 87 people vacationing in this campsite were killed by the deadliest flash flood in the history of the Pyrenees. In this case a susceptible population combined with the failure of flood control works and adequate warning and emergency action prompted the immediate transformation of exposure into vulnerability. Exposure and vulnerability coincided also in the Badajoz episode of November 1997 where 21 people were swept away by a torrential flood. In this case, victims lived in precarious housing in a low-income neighborhood unprotected against extreme events.

Tragic as these and other episodes may be (see Table I for a complete list of the most damaging floods of the last three decades) increasing exposure has not necessarily translated into increased vulnerability at least under the common metrics of human and economic losses. Although the data set used only included insured losses, Barredo et al. (2012) did not find any significant positive increasing trend in losses from floods for the period 1971-2008. To a large extent, this reduction in vulnerability is related to a parallel increase in adaptive capacity as we will attempt to document in the next section.

\section{Adaptive capacity: successes and the pending agenda}

Traditional adaptation to flooding in Spain was based in the avoidance of flood prone areas for permanent settlement; simple but effective warning systems for last minute actions, and public, religious and private charities for the affected after the event. Furthermore, for traditional agrarian societies of the semi-arid and arid areas of the
Flood policy in Spain 
DPM

25,1

8

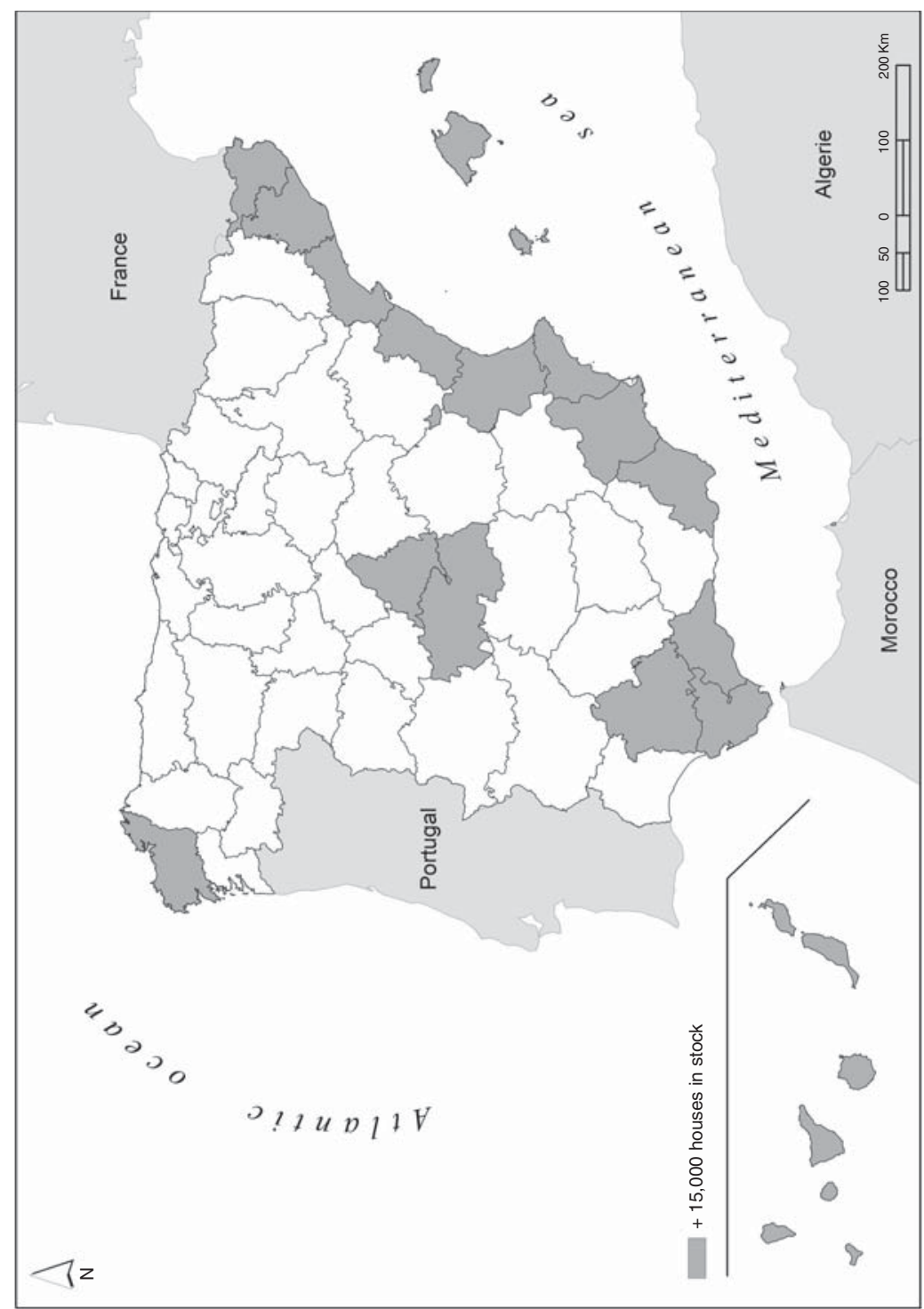

Figure 3.

$\mathrm{XXXX}_{\wedge}$ 


\begin{tabular}{|c|c|c|c|c|}
\hline Date & Episode & Deaths & Economic losses (Mill. € 2013) & $\begin{array}{l}\text { Flood policy } \\
\text { in Snain }\end{array}$ \\
\hline 1961 & El Vallés (Barcelona) & 794 & 597.0 & \\
\hline 1973 & Murcia and Almeria & 250 & 85.8 & \\
\hline \multirow[t]{2}{*}{1982} & Valencia and Alicante (October) Catalan & & & \\
\hline & Pyrenees (November) & 50 & $2,781.0$ & \\
\hline 1983 & Basque Country & 39 & $3,002.0$ & \\
\hline 1987 & Valencia, Alicante, and Murcia & 4 & $2,195.7$ & \\
\hline \multirow[t]{2}{*}{1989} & Valencia, Alicante and Murcia (September) & & & \\
\hline & Málaga (November) & 8 & 970.8 & \\
\hline 1994 & Catalonia (October) & 9 & 60.0 & \\
\hline 1996 & Biescas, Aragón (August) & 87 & 48.0 & \\
\hline 1997 & Alicante (September) Badajoz (November) & 29 & 20.0 & \\
\hline 2000 & Catalonia (June and October) Valencia (October) & 8 & 839.2 & \\
\hline 2002 & $\begin{array}{l}\text { Tenerife March) Valencia (April and May) }\end{array}$ & 10 & 117.7 & \\
\hline 2005 & Catalonia (October) & 8 & 16.7 & \\
\hline 2005 & Canary Islands (October) & 1 & 400.0 & \\
\hline 2006 & Catalonia, Valencia, Balearic Islands (September) & 1 & 100.0 & \\
\hline 2007 & Valencia (October) & 2 & 150.0 & \\
\hline 2008 & Basque Country (June) & 1 & 100.0 & Table I \\
\hline 2009 & Cordoba, Seville (December) & 3 & 200.0 & Flood episodes in \\
\hline 2010 & Cordoba, Seville (January) & 6 & $1,200.0$ & Spain (1962-2011): \\
\hline 2012 & Málaga, Almería and Murcia. (September) & 10 & 350.0 & $\begin{array}{l}\text { (1902-Z011). } \\
\text { deaths and }\end{array}$ \\
\hline \multicolumn{4}{|c|}{ Source: Compiled from Consorcio de Compensación de Seguros, 2014 and Ayala and Olcina, 2002} & economic losses \\
\hline
\end{tabular}

country, floods had a number of positive effects as well to the point that floodwaters were even subject to laws and customs regarding their ownership and control (Morales, 1989).

Modernity, which arrived in Spain comparatively late in relation to other European countries, changed this traditional adaptive framework in several important ways. First of all, flood control works slowly developed as the main adaptation in large rivers, many times after destructive floods. On the other hand, post-disaster relief was increasingly absorbed by the state which introduced legislation for very extreme events through the declaration of "zonas catastróficas" (catastrophic zones) by which all losses public and private would be assumed by the state. Furthermore, Spain developed one of the most peculiar systems of hazard insurance existing in the world today. Instead of private insurance for specific hazards, the Consorcio de Compensación de Seguros, created in 1954 provides compensation for any catastrophic extreme event, natural or social in origin. In Figure 4 we attempt to show graphically the changing relevance of different flood policy options in Spain since the 1980s. These values express in percentage the number of measures adopted between 1980 and 2014 in each of the four categories included in the chart. Percentages have been obtained according to: number of legal regulations approved in each category, number of plans regarding emergency work after a disaster episode, number of measures adopted (according to type) in each of the river basin plans, number of laws and plans regarding Civil Defence, number of Regional Land Use Plans incorporating explicitly the reduction of the flood hazard and number of institutional communication campaigns on flood hazards.

\section{Preventive measures: crisis and paradigm shift?}

Flood walls, levees, dykes, river diversions and reservoirs form part of the Spanish fluvial landscape and virtually no populated floodplain of the country remains unmodified by these structural devices. Table II lists the most prominent structural 
DPM

25,1

10

10

Figure 4.

Changing relevance of different flood policy in Spain (1980-2014)

Table II.

Main flood control plans in Spain since 1950

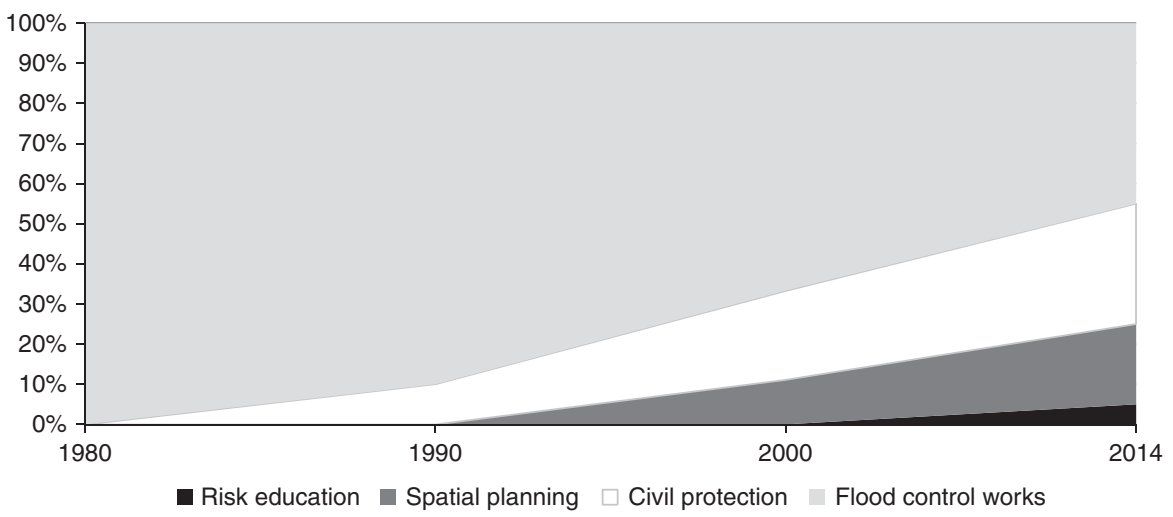

Source: Own elaboration
Flood Control Plan

Plan "South ” Turia river (Valencia)

Llobregat, Besós and a number of ephemeral

streams in the Barcelona area

New Tous dam

Several Basque rivers

Flood defence plan for the Segura basin

Flood defence for the Júcar basin

Several rivers of Almería and Málaga

Streams in Santa Cruz de Tenerife

Stormwater urban reservoirs (Barcelona)

Stormwater urban reservoirs (Alicante)

Source: Own elaboration
Flood Episode

Flood October 1957

Flood September 1962

Flood October 1982

Flood August 1983

Floods of 1973 and 1987

Floods of November 1987 and October 2000

Floods of September and November 1989

Floods of March 2002

Several episodes 1990s and 2000s

Flood September 1997

measures undertaken in Spain in the second half of the twentieth century in relation to catastrophic episodes of floods. Most of these hydraulic works have been built after catastrophic events and some have been rebuild with larger capacities (e.g. the new Tous dam) in what elsewhere has been called the "escalator effect" (Parker, 1995; Saurí et al., 2001; Serra-Llobet et al., 2013). As Gilbert White (1945) argued, flood control works based on probabilistic assessments are able to absorb most events. However, those that cannot be absorbed usually cause large disasters mostly because the damage potential of areas behind these works tends to expand after the false sense of security created by hydraulic infrastructure. This "levee effect," as White argued, is one of the most difficult issues for flood management since the theoretical "residualization" of risk usually goes hand in hand with dramatic increases in exposure.

As rivers and smaller streams have become increasingly regulated and floodplains protected with hydraulic devices, in recent years most of the investment in flood protection works has been addressed to urban drainage which has become a veritable nightmare especially for coastal tourist areas. Given the peculiar physical setting of many of these areas, backed with abrupt hills able to concentrate quickly large volumes of runoff after heavy rains, and the intense and usually unregulated urban growth processes that alter natural drainage patters, it is not surprising to find large tracts of 
land totally inundated after a storm. The hydraulic solution to this coastal drainage has been for the most part to turn ephemeral streams in urban areas into sewers keeping them underground and therefore away from public sight.

Socially, flood protection hydraulic works are generally well accepted by the population especially at the local level where city councils strive for regional and national authorities to fund these infrastructures. Given the level of development in flood prone areas, flood control works are usually justified as the only feasible way to avoid large flood impacts. However, and especially since the crisis of the mid-2000, public authorities are becoming reluctant to plan and fund large programs of streams and catchment hydraulic modification to reduce the possibilities of flooding. In part, this is related to fiscal and budgetary constraints and the dire financial situation of some regional water agencies in charge of these programs such as the Catalan Water Agency (Sauri, 2011). However, while the economic crisis has affected public budgets for flood protection, we have not observed an increase in the frequency of flood-related disasters since 2008.

The economic crisis beginning in 2008 has left another interesting imprint in the financing of hydraulic infrastructures. As said before, these infrastructures had been usually declared of "public interest" and therefore their costs assumed exclusively by the central state. However, a change in the scale of governance of floods with greater amplitude for the local level (Renn, 2008) may open risk governance to a group of actors which can include private companies, civil society associations, experts and staff from other public administrations. In Spain, the River Basin Advisory Boards have opened their doors to scientists, environmental NGOs and other groups although these groups always stand in minority in front of the much more powerful vested interest of irrigators, hydropower companies or staff from the river authorities.

One interesting angle of this incipient social participation in the management of large hydraulic infrastructure concerns funding. National and regional governments are seeking now to transfer part of costs of hydraulic works to local governments and individuals precisely under this argument of growing collaboration and participation in risk management. For example, after the flood of October 2005 in the central Costa Brava area of Catalonia, it was decided that the Ridaura river would be contained with flood walls. However, the public authority asked the locality of Calonge to provide 25 percent of the funding needed to complete such project. On the other hand, water authorities are also increasingly sceptical about proposals for flood control works coming from the local and neighborhood spheres which sometimes are characteristically dismissed as no more than "Berlin Walls."

At any rate, toward 2010 it could be said that most rivers with flood potential flowing into urban and tourist areas, especially along the Mediterranean, had been already subjected to some form of hydraulic control. Moreover, funding for flood control works has been dwindling in recent years due to other, perhaps more pressing concerns in other areas of the water cycle, especially water supply operations and above all, wastewater treatment plants to comply with European regulations and that take now the lion's share of the budget of water-related projects. In Catalonia, for example, of the budget for 2006-2015 (about 9.4 billion euro) only 10 percent is estimated to go to "actions to improve the quality of river environments" were flood control works are situated.

Therefore, pending projects, however, had to face not only growing budgetary constraints and the need to reduce investments but also a certain change of perspective on the flood issue by which other alternatives to flood control works were beginning to
Flood policy in Spain 
DPM

25,1

be considered. Thus instead of using the traditional military parlance of "defending against floods" more and more was being heard about "living with floods" in accordance with the European Directive of 2007. This new approach acknowledges that floods are impossible to eliminate and that therefore, hydraulic solutions may have to start sharing room with other alternatives, most especially land use planning in flood prone areas.

This shift from structural (hydraulic) to non-structural (land use planning) flood prevention measures has also been favoured by more and more clear definition of the responsibilities of the hydraulic authority when deciding the uses permitted in areas prone to flooding. Thus, the reform of the Spanish Water Act of 1985, issued in 2008, implied that the "Zona de Servidumbre" (five meters on either side of the channel to coincide with what would be the maximum ordinary flood), while it could be privately owned had to be devoted to public environmental uses. Within the limits of the "Zona de Policía" ("Zone of Policing") which roughly coincides with the avenue with a return period of 100 years, any action regarding use required authorization by the public regulator. Beyond this zone, however, the river authority may inform or recommend but not authorize or prohibit proposed land uses as local land use plans have the final say in these matters. In all cases, flood maps become an essential tool but also one tool that needs constant revision given the highly dynamic nature of human occupation and transformation of fluvial environments. It must be said that flood mapping in Spain has advanced considerably during the last decades and many areas today already have these maps at detailed scales (Pérez-Morales, 2012).

\section{Flood management during the event}

Flood warning systems have improved enormously after continuous technological progress in the capture and processing of rain and flood-related data. Radar technology is now widely available especially in the more problematic Mediterranean basins as an automated system of transmission of rainfall and river flow data in real time. Short-term predictive models of weather conditions have become also of common use and form also the basis for intense rainfall and/or flooding episodes. Given the enormous complexities associated with Mediterranean weather forecasting, prediction at small scales remains unattainable and will probably continue to be so in the near future. According to data analyzed for the whole of Spain (Gallego et al., 2011), since 1980 the Mediterranean area has observed a negative trend in annual precipitation and also a certain bias toward the concentration of precipitation in the autumn months (Cortesi et al., 2012). This may indicate an increase in rainfall intensity from September to November which explains partially many of the flood disaster episodes occurred since 1980 in Mediterranean Spain (Olcina, 2009). Predictions for this century confirm these trends; that is, decreasing amounts of rain together with a larger concentration of intense rain events in the autumn months (Agencia Estatal de Meteorología (AEMET), 2015). Hence predictions are always expressed in probabilistic terms of the amount of rainfall expected. Much better are the channels to transmit flood warnings to the public through the Spanish Meteorological service or similar region-based offices. In this respect, since 1987 specific campaigns for meteorological prediction in the Mediterranean have been implemented. All these actions have evolved into a National System of Meteorological Warning which has been integrated into the European System of Meteorological Warnings (Ayala and Olcina, 2002).

Emergency planning has also taken large steps in recent years. As said before, Civil Defense in the country was created in 1982 and a specific law regulating its activities was promulgated in 1985. Since 1985 and regarding floods, a number of legal instruments 
have been issued most of them related to procedures to follow in case of emergencies by floods. In 2014, autonomous communities had approved Civil Protection Plans against floods modeled after the Spanish guidelines on protection against floods issued in 1995. An important emphasis has been put on emergency planning at the local level. Municipalities must develop a Basic Municipal Emergency Plan if they have a population of 20,000 inhabitants or more, or if they are considered as tourist centers under current law. Action Plans for flooding must be prepared if, according to flood maps, municipalities fall within the categories of "moderate" and "high" risk. In Spain even today 85 percent of municipalities lack flood emergency plans adapted to European, national or regional risk management and civil protection legislations (Olcina, 2009).

In sum, while the Spanish effort in the area of flood emergency planning has to be praised, many obstacles remain, for instance, the low proportion of fully certified local emergency plans, the endemic lack of funding for making plans operational, and the impossibility of enforcing provisions through fines and other penalties. This situation contrasts with a very demanding public when emergencies appear and anything going "wrong" finds immediately someone to blame for.

\section{Flood management post event}

Post-disaster relief and insurance remain the two basic strategies in this phase. In the first case it must be remembered that most economic losses caused by floods in Spain tend to concentrate in public goods and services, especially infrastructures. Also many times these infrastructures are owned and managed by local councils who must invest heavily in substitutions and replacements. Post-disaster relief may take a variety of forms, ranging from economic incentives, tax cuts, etc., to the provision of damaged public goods and services, and occasionally to direct payments for those most heavily hit by the disaster. Spanish relief legislation includes the possibility of declaring as "Catastrophic Zone" an area particularly affected by a natural or technological hazards. In this case, the state takes care absolutely of all public and private costs and provides the adequate compensations. During the 1980s a number of "Zonas Catastróficas" were recognized by the Spanish government after the damaging floods occurring in Valencia, Murcia and Andalucía. However, in the 1990s and after, this type of overall provision of relief has been replaced by partial relief funding. On the one hand this could be interpreted positively, namely that the country has not known flood disasters comparable to those of the 1980s and 1990s. But on the other hand it may also indicate reluctance by the state to provide support for all economic losses.

As for insurance, the Insurance Compensation Consortium (CCS), an organization of the Ministry of Economy and Finance, can compensate individuals and institutions for any damage as a result of natural hazards. The evolution of the amounts paid by the CCS (see Figure 5) over the last decade suggests not so much an increase in the frequency of extreme events of nature as greater penetration of insurance and, above all, an increasing accumulation of goods and services in flood prone areas. While this system has the advantage of making flood insurance available for all it does not penalize exposition to floods. Between 1971 and 2013 the CCS processed some 500,000 damage claims with a total amount of 5,338 million euro (65 percent of the total claims paid). In Table III we present the most important flood episodes according to compensations paid by the CCS.

\section{Land use planning for flood control. An intractable problem?}

Of all the management options reviewed, one in particular appears to be especially difficult to implement: the regulation of land uses in flood prone areas. While the social
Flood policy in Spain 
DPM

25,1

\section{4}

Figure 5.

Compensations

paid by the

Consorcio de

Compensación

de Seguros

(in thousands $€$ )

(1984-2013)
The ten largest flood episodes in Spain according to compensations paid

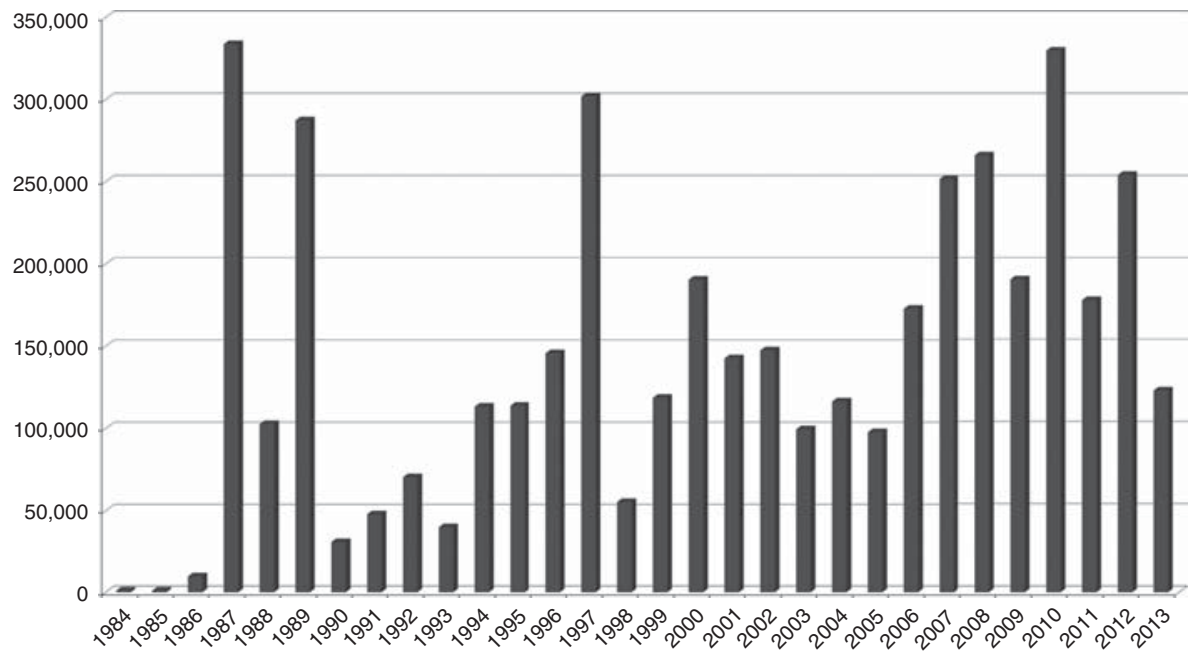

Source: Consorcio de Compensación de Seguros, 2014

\begin{tabular}{llr}
\hline Date & Area & Compensations paid \\
\hline August 1983 & Basque Country & 815.8 \\
November 1987 & Valencia, Murcia & 287.9 \\
October 1982 (Tous dam) & Valencia & 219.8 \\
September 2012 & Andalusia, Murcia & 219.3 \\
November 1989 & Málaga & 161.1 \\
June 1997 & Basque Country & 110.0 \\
October 2000 & Valencia, Murcia & 100.3 \\
November 2005 & Canary Island & 98.0 \\
October 2007 & Valencia & 94.9 \\
October 1994 & Catalonia & 77.9
\end{tabular}

Source: Adapted from Consorcio de Compensación de Seguros (2014)

and environmental benefits of this option are self-evident, reluctance to widen the scope of this action is widespread. The approval of the European Directive on Floods (EU 60/2007) may give some impetus to land use planning but the materialization of such policies remains elusive.

In Spain, land development in flood prone area represents one of the more blatant contradictions between legal texts and actual facts. Since the late 1980s, some regions holding executive powers in territorial and urban planning proceeded to pass legislation on land use planning (see Table IV). One common and novel thread of much of this legislation was to include natural hazards and especially floods as key elements in deciding whether or not and under what circumstances a particular area could be subject to development. At the National level, the modification of the Land Use Act of 1992 in 1998 represented the first attempt toward the incorporation of risk analysis in territorial and urban planning. However, the Spanish land use law of 1998 stated that the presence of a hazard needed "proof" in form of adequate mapping. Since this cartography has not been available until very recently and remains incomplete for 
many areas, the "burden of proof" fell generally on anti-development side who could offer no argument against specific proposals. Later in 2008, this shortcoming was partially solved since the modified law of that year required the elaboration of risk maps for any new urban development.

Therefore and to a large extent influenced by European legislation on land use and water planning, current Spanish legislation states that risk analysis and the corresponding maps must be an integral part of the planning process. In this regard, and in compliance with Directive 60/2007, a large database of flood risk mapping of Spain (scale 1/10:000), the National Flood Zone Mapping of Spain, is being developed. Prior to the completion of the mapping database, "preliminary risk assessments" for flood prone areas in the different river basins must be prepared.

While all these initiatives must be applauded the crucial issue is still who has the authority to grant or deny permits for development in flood prone land. Even if, based on cartographic information, the hydraulic authority may recommend the prohibition of some urban developments, the final decision still lies in the hands of local and regional land use commissions. Moreover, it is well known that maps are controversial since they may depend on extrapolations, conflicting data, expert opinion and other factors. The picture is further complicated by the pressing needs for development during periods of economic hardship such as those being currently experienced in Spain.

\section{Conclusions}

Since 1980, flood policy in Spain has expanded its scope of actions toward a more comprehensive consideration of White's "range of choice" or, in other words, toward a higher adaptive capacity to floods. Perhaps the area where more progress has been made concerns flood forecasting and warning systems and emergency planning. Hydraulic intensification in the form of more flood control works has continued in the major streams and also in smaller streams in urban areas. However, diffuse flooding especially as urban drainage, many times a product of unplanned urban growth, still represents a major problem in urban and tourist areas of the Mediterranean and the islands. Flood prevention through land use controls remains elusive for several reasons, including the lack of comprehensive maps at adequate scales, the secondary position of water authorities in decision making, and the well-known conflicts between conservation and development at the local level. In Spain, the lack or infancy of many

\begin{tabular}{|c|c|c|}
\hline Law and/or plan & Hazard & Scale \\
\hline Reforms of the land law (1998 y 2008) & All & $\begin{array}{l}\text { National with application in local } \\
\text { areas }\end{array}$ \\
\hline $\begin{array}{l}\text { Directive 60/2007. National mapping system } \\
\text { of flood areas (SNCZI) }\end{array}$ & Floods & National (river basins) \\
\hline $\begin{array}{l}\text { Flood protection plans (Law of the National } \\
\text { Water Plan, 2001) }\end{array}$ & Flood & National (river basins) \\
\hline Emergency plans (civil protection) & $\begin{array}{l}\text { Floods, seismic } \\
\text { and volcanic }\end{array}$ & $\begin{array}{l}\text { National with application in local } \\
\text { and regional areas }\end{array}$ \\
\hline Regional land use plans & All & Regional \\
\hline Regional land use plans to reduce flooding & Flood & Regional \\
\hline Local land use plans to reduce flooding & Flood & Local \\
\hline
\end{tabular}

Source: Own elaboration
Flood policy
in Spain 
$\mathrm{DPM}$

25,1

land use regulations stands behind the tremendous increase in flood exposure observed during the years of the urbanization "tsunami."

While vulnerability to floods may have decreased in Spain, the future may hold different and potentially negative scenarios in the frequency and magnitude of flood events especially regarding the effects of climate change. Climate models point toward an intensification of flooding episodes in Mediterranean areas as well as in the Canary Islands for the following decades (IPCC 2013/14). Facing this, the European Union has been launching in recent years a number of initiatives to reduce risk of hydrological extremes. Thus and besides the European Flood Directive (60/2007), the European Union has issued two documents of interest for water planning and management: Plan to Safeguard the Water Resources of Europe (2012) and the Strategy for Adaptation to Climate Change in the $\mathrm{EU}_{\Lambda}(2013)$. Both include a number of actions to reduce vulnerability and exposure to water extremes which emphasize land use planning. However, Spain has yet to implement the risk reduction measures proposed in those plans. Since the early 1980s, flood policy in Spain has grown more complex and is likely to evolve in the same direction during the following decades. Flood control works and post-disaster assistance, albeit still important, are no longer the main pillars supporting flood policy, and warning and emergency actions, land use planning and insurance have increasingly taken a more prominent role. As in other countries, two main issues merit future work in our opinion: first the management of low probability high-consequence events (especially in the highly exposed areas of the urbanized Mediterranean coast) and second, the management of the positive aspects of flooding (groundwater recharge, soil fertility, protection of wetland and riverine environments, etc.). Both reflect the dual nature of these episodes as hazards but also as resources. Future flood policy should therefore attempt to reduce the former and increase the latter.

\section{References}

Agencia Estatal de Meteorología (AEMET) (2015), "Proyecciones Climáticas para el siglo XXI en España", available at: www.aemet.es/es/serviciosclimaticos/cambio_climat (accessed July 10, 2015).

Ayala, F.J. and Olcina, J. (2002), Riesgos Naturales, Ariel, Barcelona.

Barredo, J.I., Saurí, D. and Llasat, M.C. (2012), “Assessing trends in insured losses. From floods in Spain. 1971-2008”, Natural Hazards and Earth System Science, No. 12, pp. 1723-1729.

Consorcio de Compensación de Seguros (2014), "Estadística. Riesgos extraordinarios 1971-2013” available at: www.consorseguros.es/web/c/document_library/get_file?uuid =548d4f59b6c5-40dd-b06b-98dbcefd790f\&groupId = 10124 (accessed October 10, 2014).

Cortesi, N., González-Hidalgo, J.C., Brunetti, M. and Martin-Vide, J. (2012), "Daily precipitation concentration across Europe 1971-2010”, Natural Hazards and Earth System Science, Vol. 12 No. 9, pp. 2799-2810.

Departament d'Interior, Direcció General de Protecció Civil, Generalitat de Catalunya (2014), "Pla de Protecció Civil per al Risc d'Inundacions a Catalunya (INUNCAT)", available at: www20.gencat.cat/portal/site/interior/ (accessed September 10, 2014).

Departament de Territori i Sostenibilitat, Generalitat de Catalunya (2014), "Estadístiques i Indicadors d'Habitatge", available at: www20.gencat.cat/portal/site/habitatge/ (accessed September 10, 2014). 
Gallego, M.C., Trigo, R.M., Vaquero, J.M., Brunet, M., García, J.A., Sigró, J. and Valente, M.A. (2011), "Trends in frequency indices of daily precipitation over the Iberian Peninsula during the last century", Journal of Geophysical Research: Atmospheres (1984-2012), Vol. 116 No. D2.

\section{Q6}

Generalitat Valenciana (2013), "Plan de Acción Territorial del Riesgo de Inundaciones en la Comunidad Valenciana (PATRICOVA)” Revisión, Consellería de Infrae structuras, Territorio y Medio Ambiente, available at: www.citma.gva.es/ca/web/ planificacion-territorial-e-infraestructura-verde/revision-del-patricova-85207 (accessed October 10, 2014).

Guha-Sapir, R. and Hoyois, P.H. (2015), "EM-DAT: International Disaster Database EM-DAT", available at: www.emdat.be/ (accessed May 4, 2015).

Mateu, J. (2000), "El contexto geomorfológico en las inundaciones de la Ribera del Júcar", Cuadernos de Geografía, Nos 67/68, pp. 242-259.

Morales, A. (1989), "Abandono y desorganización de los sistemas de riegos de turbias. $\mathrm{Su}$ incidencia en la escorrentía”, in AAVV (Ed.), Los paisajes del agua. Libro jubilar dedicado al profesor Antonio López Gómez, Universidad de Valencia y Universidad de Alicante, Valencia, pp. 199-204.

Olcina, J. (2009), “Cambio climático y riesgos climáticos en España”, Investigaciones Geográficas, No. 49 , pp. 197-220.

Ollero, A., Ibisate, A., Granado, D. and Real de Asua, R. (2015), "Channel responses to global change and local impacts: perspectives and tools for floodplain management (Ebro River and tributaries, NE Spain)", in Hudson, P. and Middelkoop, H. (Eds), Geomorphic Approaches to Integrated Floodplain Management of Lowland Fluvial Systems in North America and Europe, Springer, New York, NY, pp. 27-52.

Parker, D. (1995), "Floodplain development policy in England and Wales”, Applied Geography, Vol. 15 No. 4, pp. 341-363.

Pérez-Morales, A. (2012), "Estado actual de la cartografía de los riesgos de inundación y su aplicación en la ordenación del territorio. El caso de la Región de Murcia”, Boletín de la Asociación de Geógrafos Españoles, No. 58, pp. 57-82.

Perles, M.J. (2010), “Apuntes para la evaluación de la vulnerabilidad social frente al riesgo de inundación”, Baetica, No. 32, pp. 67-87.

Renn, O. (2008), Risk Governance: Coping with Uncertainty in a Complex Worl, Taylor and Francis Group, London.

Q8 Sauri, D. (2011), "Crisi econòmica i riscos naturals", Revista Catalana de Seguretat Pública, Vol. 24, pp. $27-44$.

Saurí, D., Roset, D., Ribas, A. and Pujol, P. (2001), "The escalator effect in flood policy: the case of the Costa Brava, Catalonia, Spain”, Applied Geography ^No. 21, pp. 127-143.

Serra-Llobet, A., Tabara, J.D. and Saurí, D. (2013), "The Tous dam disaster of 1982 and the origins of integrated flood risk management in Spain", Natural Hazards, Vol. 65 No. 3, pp. 1981-1998.

Vilaplana, J.M. (2008), "RISKAT. Els riscos naturals a Catalunya, Informes del CADS 6", Generalitat de Catalunya, Barcelona.

Warner, J.F., Van Buuren, A. and Edelenbos, J. (Eds) (2013), Making Space for the River: Governance Experiences with Multifunctional River Flood Management in the US and in Europe, IWA Publishing, Chicago, IL.

White, G.F. (1945), Human Adjustments to Floods, University of Chicago, Department of Geography, Chicago, IL.

White, G.F., Kates, R.W. and Burton, I. (2001), "Knowing better and losing even more: the use of knowledge in hazards management", Environmental Hazards, No. 3, pp. 81-92. 
DPM

25,1

18

\section{Further Reading}

Biron, P.M., Buffin-Bélanger, T., Larocque, M., Choné, G., Cloutier, C.A., Ouellet, M.A., Demers, S., Olsen, T., Desjarlais, C. and Eyquem, J. (2014), "Freedom space for rivers: a sustainable management approach to enhance river resilience", Environmental Management, Vol. 54 No. 5, pp. 1056-1073.

Instituto Nacional de Estadística (INE) ( (nd), “Censos de población, 2001 and 2011”, available at: www.ine.es/inebmenu/mnu_cifraspob.htm (accessed October 10, 2014).

Ministerio de Fomento (2012), Informe sobre el stock de vivienda nueva 2012, Ministerio de Fomento, Madrid.

\section{Corresponding author}

Professor Maria Hernández can be contacted at: maria.hernandez@ua.es

For instructions on how to order reprints of this article, please visit our website: 